\title{
TENSION WOOD FORMED IN FAGUS SYLVATICA AND ALNUS GLUTINOSA AFTER SIMULATED MASS MOVEMENT EVENTS
}

\author{
Ingo Heinrich ${ }^{1}$, Holger Gärtner ${ }^{2}$ and Michel Monbaron ${ }^{1}$
}

\begin{abstract}
SUMMARY
Due to the likelihood of global climate change, the frequency and magnitude of natural hazards such as mass movements may likewise change, thus favouring the refinement of methods to detect and quantify geomorphic events when precise records are not available. Geomorphic events typically have a significant effect on tree growth, e.g., reaction wood marked by changes in ring widths and wood density. To date, several dendroecological techniques have been developed to document the occurrence of these events but it rarely has been possible to retrieve additional information from reaction wood concerning the precise kind and intensity of geomorphic events. Additional qualitative information inferred from reaction wood of trees holds the potential to not only document but also estimate important characteristics of natural hazard events. To refine the methods already used in dendrogeomorpology, experiments simulating various geomorphic events were used to monitor subsequent wood anatomical responses of Fagus sylvatica and Alnus glutinosa. The preliminary results indicate that these two common broadleaf tree species show variations in their reactions to different experimental treatments.
\end{abstract}

Key words: Wood anatomy, reaction wood, puncher samples, geomorphic process.

\section{INTRODUCTION}

Anatomical responses in coniferous wood have often been used for dating catastrophic mass movement events, whereas similar studies of broadleaf species are comparatively rare. However, broadleaf species often grow in mixed forests together with conifers and are sometimes the dominant species at lower elevations. Furthermore, broadleaf species possess a more complex wood anatomy and offer structural features for further analysis not found in coniferous wood (Schweingruber 2001).

In mountainous terrain, mass movements such as rock falls, landslides, debris flows and soil creep usually have distinct impacts on trees that alter their growth dramatically. Several types of dendroecological techniques have been developed to determine frequencies of such events, e.g., change from concentric to eccentric rings, onset of reaction wood formation, and the dating of scars (Schweingruber 1996). These methods have

1) Department of Geosciences, Geography, University of Fribourg, 1700 Fribourg, Switzerland. Present address: ICG-V, Research Centre Jülich GmbH, Leo-Brandt-Str., 52325 Jülich, Germany [E-mail: i.heinrich@fz-juelich.de].

2) Swiss Federal Research Institute WSL, Zürcherstrasse 111, 8903 Birmensdorf, Switzerland.

Associate Editor: Thomas Yanosky 
been independently used with only small modifications over the last two decades and, combined with traditional techniques such as geomorphological mappings, often permit the dating of events to the nearest year (Gärtner et al. 2003), thus providing important information to the field of natural hazard research.

Rarely has it been possible to retrieve detailed information from reaction wood alone, for example, particularly regarding the severity of mass movements (Clague $\&$ Souther 1982). The ability to date mass movement events intra-seasonally and also to retrieve more qualitative details would be particularly helpful because at present tree-ring responses to different mass movements such as debris flows and avalanches cannot be distinguished. A comprehensive wood anatomical analysis of reaction wood induced artificially as part of a growth experiment has the potential to provide more complete information on potentially different tree-growth reactions to these dissimilar events.

Broadleaf trees form tension wood in direct response to mechanical forces that misalign stems from optimum equilibrium (Wardrop 1956; Scurfield 1973). General features of tension wood are enhancement of radial growth on the upper side of leaning trunks, silvery sheen visible in cross sections, production of gelatinous fibres, low lignin and high cellulose contents, and a reduction in vessel size and number (Bland \& Scurfield 1964; Côté \& Day Jr. 1965; Hughes 1965).

Although this definition is commonly used, it has been shown that tension wood also can vary depending on the species itself, physiological status, parts of the tree affected, type and duration of mechanical impact, and climatic conditions (Sachsse 1961a; Wardrop 1964; Côté \& Day Jr. 1965; Arganbright \& Bensend 1968; Nicholson 1973; Nicholson et al. 1975). A better understanding of tension-wood development, therefore, is of basic interest and practical importance (Kennedy \& Farrar 1965). Although attempts have been made to classify compression wood on the basis of severity (e.g., Yumoto et al. 1983) such classifications do not exist for any broadleaf species. Such a classification holds the potential to calibrate wood anatomical reactions to growth stresses of various kinds and strengths.

The general lack of studies of tension wood is probably due to the difficulty of detection without detailed microscopic examination and its high structural variability. Additionally, Höster and Liese (1966) showed that some broadleaf species form little or no tension wood at all. In view of these limitations and the restricted use of tension wood for characterising past mass movements, analysis of its formation under controlled growing conditions may enable dendrogeomorphological studies in vegetation zones dominated by these trees.

Because of these uncertainties we decided to concentrate on two common broadleaf species, namely European beech (Fagus sylvatica L.) and European alder (Alnus glutinosa (L.) Gaertn.). Both species form distinct tension wood (Höster \& Liese 1966). Fundamental reaction wood properties have been studied in beech (Chow 1946; Sachsse 1961b; Trénard \& Guéneau 1975, Tesari \& Mattheck 1999; Mattheck et al. 2000; Clair \& Thibaut. 2001) and alder (Willits et al. 1990; Lowell \& Krahmer 1993; Wilson \& Gartner 1996). It is hoped that the additional application of wood anatomical techniques can provide supplementary information about the type, size and intensity of 
past hazardous impacts on the growth of broadleaf trees. As part of an ongoing growth experiment, samples of tension wood were collected from living trees. The experiment attempted to simulate the effects of geomorphic events and to detect growth responses to a range of mechanical stresses.

\section{MATERIALS AND METHODS}

Growth experiments were set up in Switzerland with European beech and European alder near Krattigen $\left(7^{\circ} 45^{\prime} / 46^{\circ} 38^{\prime}, 840 \mathrm{~m}\right.$ asl, Bernese Oberland) and near Posieux $\left(7^{\circ} 08^{\prime} /\right.$ $46^{\circ} 45^{\prime}, 600 \mathrm{~m}$ asl, Canton of Fribourg), respectively, at the end of tree dormancy in March 2004. The treated specimens at both sites were mainly young trees still flexible enough to be bent to $80^{\circ}$ without breaking the stem (diameters $4-10 \mathrm{~cm}$ ). The forest stand in Krattigen contains 10- to 20-year-old beech re-growth which developed following heavy storm damage, and the stand of European alder in Posieux was planted for re-vegetation purposes approximately ten years ago. At both sites nine treatment groups containing four trees each were selected (Table 1). Some of the treatments were inspired by earlier experiments conducted by others. For example, treatments 1 and 2 were developed by Robards (1966) to investigate the degree of eccentricity and production of tension wood in willow related to the angle of displacement from the vertical.

Table 1. List of different treatment groups containing four trees per species and treatment.

T1 Stem bent to $80^{\circ}$ from the vertical

T2 Stem bent to $45^{\circ}$ from the vertical

T3 Stem bent increasingly in time starting from small angles up to $80^{\circ}$

T4 Stem bent to $80^{\circ}$, but with the apex remaining vertical

T5 Stem bent to $80^{\circ}$, with apex cut

T6 Stem bent to $80^{\circ}$, but with the bark and cambium partly removed from the upper side

T7 Stem bent to $80^{\circ}$, but with the bark and cambium partly removed from the lower side

T8 Stem bent to $80^{\circ}$ and sideways

T9 Reference group

Treatment group 3 purported to study the reaction wood in trees due to recurring slow mass movements (Alestalo 1971). The trees were first bent to $30^{\circ}$ in March 2004, then to $45^{\circ}$ in April, and finally to $80^{\circ}$ in May. Experiment 4 was devised by Wardrop (1964) on eucalypts in Australia and was repeated in the current study to simulate a tree tilted horizontally but with the upper part of the crown leaning against an obstacle and thus remaining vertical. Treatments 5 and 8, first devised by Burns (1920), were designed to test growth responses to a changed equilibrium within the tree's architecture. For example, a tree could be tilted horizontally and have lost its apex during or after the event. Experiments 6 and 7, first described by Wardrop (1956) for eucalypts, test the hypothesis that partly removing the bark from the upper side of a leaning tree can result in the production of reaction wood. This scenario can occur when a tilted tree is damaged during a mass movement event. Finally, group 9 contains four untreated reference trees. 
Figure 1. Increment puncher used for collecting minute samples of tension wood (Forster et al. 2000).

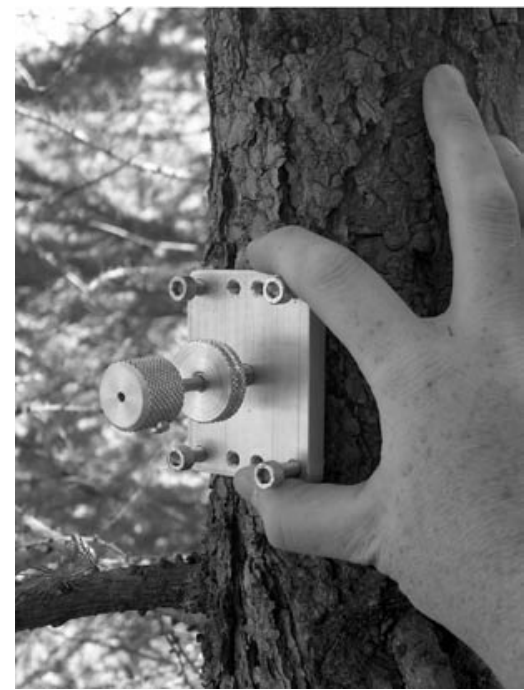

At the end of the growing season in 2004, four increment puncher samples were taken from the tension wood side of one tree selected randomly from each group (Fig. 1). The puncher takes minute samples approximately $1 \mathrm{~mm}$ in diameter from the cambial zone and the adjacent ring without otherwise disturbing growth during the experiment (Forster et al. 2000).

The puncher samples were glued on small holders and transverse $15-\mu \mathrm{m}$ sections were cut with a sliding microtome and stained using astrablue and safranin according to standard techniques (Schweingruber 2001). A Zeiss Axioskop equipped with a digital camera was utilised to conduct light microscopy and photographs were taken of the sections under various magnifications. Photos were examined for structural changes formed during the experiment. The dimensions of wood anatomical features, that is, cell wall and lumen areas of fibres and total lumen area of the vessels, were determined by digital imagery utilising the software program WinCELL Pro 2005a. Although the system permits automatic object recognition, each analysis also was visually checked by the operator and, if necessary, manually corrected. The influence of the different treatments on subsequent growth was determined quantitatively using the software package S-PLUS. The analysis started with an assessment of the normality of the data using histograms. The distribution of the data was skewed and had to be log-transformed in order to conform to a normal distribution before further analysis. The S-PLUS diagnostic plots, e.g., residual plots and Cook's distance were used to ensure constant variance and absence of outliers, respectively (Cook \& Weisberg 1999). Analysis of variance (ANOVA) was conducted to test the variances of the vessel lumen areas between and within groups T1 to T8. For an a posteriori examination of the vessel-area variations between the treatment groups, box-whisker plots were created. In general, box-plots allow a quick and easy comparison of the means and spread of the data. Any two data sets are considered significantly different if one box does not overlap the median of a second box, provided that data are distributed normally (Cleveland 1994). 


\section{RESULTS AND DISCUSSION}

We applied eight different mechanical treatments and proposed that differences in the tension wood formed would be discernible. We hypothesised that tension wood would be more fully developed after severe bending and that tension wood formation would be altered if the tree is not only bent but also modified in other ways, such as by wounding (Wilson \& Gartner 1996; Mattheck et al. 2000).

Typical tension wood and normal stem increment growth in alder and beech are illustrated in Figures 2 and 3. The tension wood contains denser fibres and fewer and smaller vessels. Furthermore, no vessels developed in the earliest part of the rings. The denser tissue implies that initial growth resulted in increased stabilisation of the tree rather than the production of new conducting tissue. This differs from the responses of two coniferous species, Picea abies (L.) Karsten and Larix decidua P. Mill., also treated in the course of this experiment (Gärtner et al. unpubl. data.), in which the first radial files were typical earlywood tracheids with thin cell walls and large lumens. However, it is unknown whether differences in the wall- and lumen-dimensions of first-formed cells in the broadleaved and coniferous trees represent different growth strategies that
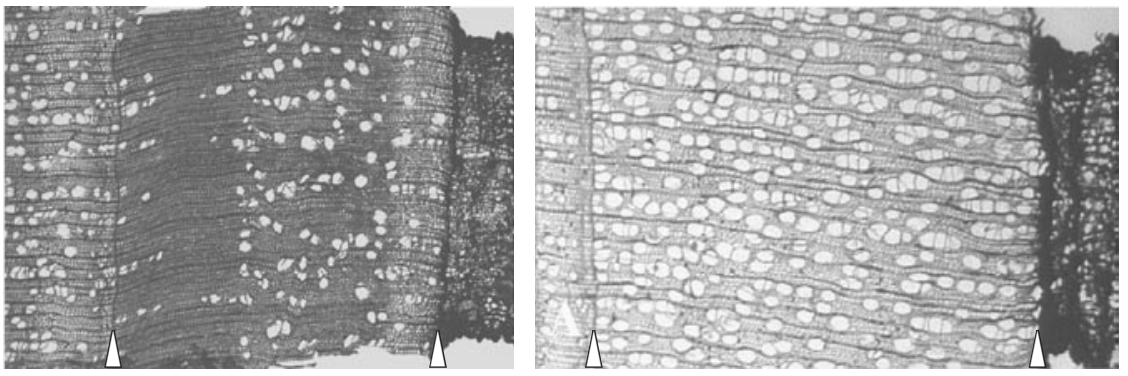

Figure 2. Light microscopy photos of microsections cut from an alder of treatment group T1 (strongest bending) (left) and an untreated reference tree (right) at site Posieux, Fribourg; treering boundaries indicated by arrows (magnification in both photos: $\times 25$ ).
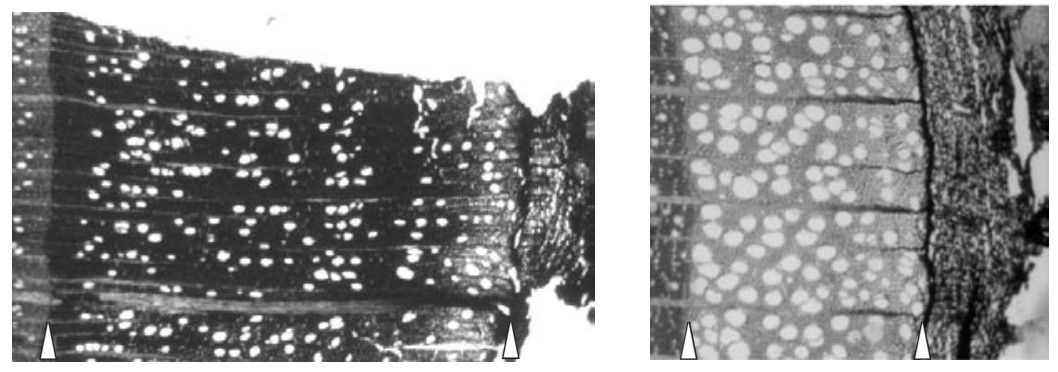

Figure 3. Light microscopy photos of microsections cut from a beech of treatment group T1 (strongest bending) (left) and an untreated reference tree (right) at site Krattigen; tree-ring boundaries indicated by arrows (magnification in both photos: $\times 25$ ). 

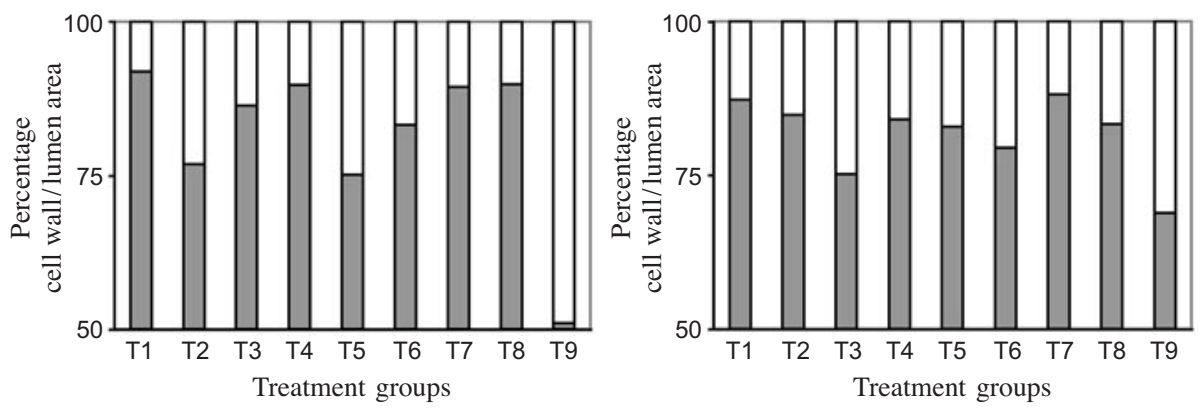

Figure 4. Percentage area covered by fibre cell wall (grey) and fibre cell lumen (white) per treatment (T1-8; treatment T9 is the untreated reference group) for alder (left) and beech (right).

first favour either stem stabilisation (study trees) or conductance (conifers), or if differences are related more generally to the complex wood anatomy of diffuse-porous trees.

Visual impressions were confirmed by digital imagery analysis. Both species displayed substantial differences between treatment and reference groups (Fig. 4). In alder, the percentage of cell wall material was greatest in group T1 (strongest bending), smallest in groups T2 (weakest bending) and T6 (cambium damaged at upper side), and in the reference group. In beech, cell wall percentages were greatest in groups T1 (strongest bending) and T7 (cambium damaged at lower side) whereas the reference group and T3 (increasing bend) displayed the smallest values. These differences suggest that treatments induced tension wood in both species that varied among groups in response to the treatments themselves. These results are similar to those found in crack willow (Salix fragilis L.) by Robards (1966), who noted that tension wood was more fully developed in stems bent to a $120^{\circ}$ lean than in those at a $90^{\circ}$ lean. Results of our study strengthen the feasibility of differentiating tension wood into classes, comparable to those proposed for conifers by Yumoto et al. (1983). Severe mechanical stress appears to increase the deposition of cell wall material and decrease the dimensions of cell lumens more so than does less stress, e.g., decreasing mechanical stresses in groups $\mathrm{T} 1$ to $\mathrm{T} 3$ are paralleled by a decreasing gradient of cell wall material. In both species, the more intensive treatments in $\mathrm{T} 1$ resulted in tension wood that is denser than that in group $\mathrm{T} 3$.

The percentage of cell wall material in fibres of both species was greater in T7 (cambium damaged at lower side) than in T6 (cambium damaged at upper side). Trees in both treatment groups were bent $80^{\circ}$ from the vertical; however, in T6, bark and cambium were partly removed from the upper side of the inclined stem above the bend, whereas the bark and cambium in T7 were stripped from below the bend. This result suggests that the induction of reaction wood might be controlled from the upper part of trees and that tissue removed from the upper side in T6 may have hindered the flow of hormones and other substances that regulate the production of tension wood (Strasburger et al. 2002). The fibres had smaller percentages of cell walls in both species in T4 (apex vertical) and, particularly, in T5 (apex cut) than in T1 (strongest bending), 
suggesting that tension wood is less completely formed when the apex was vertical or cut. These results thus imply that the position and integrity of the apex are important in the formation of tension wood, and that alterations to the apex may lead to subsequent variations in the anatomical composition of tension wood. Accordingly, factors such as the dimensions of cell walls and lumens might be used as differential indicators of reaction wood formation, assuming that trees were bent but otherwise undamaged. These findings are similar to those of Wardrop $(1954,1964)$, who found that tension wood in eucalypts formed when the apex was cut following bending of trees into the horizontal position, but little tension wood developed if the apex was cut before the trees were bent. Furthermore, Wardrop (1956) found that the removal of the bark from the upper part resulted in less developed tension wood than when bark was removed on the lower side, a finding confirmed in treatments T4 to T7 of our experiment.

The total area of vessel lumens seems to have changed in response to the different treatments, as well. The analysis of variance (Table 2) suggests that vessel lumen areas differ more between than within the treatment groups, implying that treatments resulted in changes in vessel morphologies. The box-whisker plots (Fig. 5) suggest a progres-

Table 2. Analysis of variance (ANOVA) of total vessel lumen area for alder and beech.

\begin{tabular}{lrcc}
\hline Species & F & P-value & F crit \\
\hline Alder & 19.52233 & $6.39 \mathrm{E}-23$ & 2.02935 \\
Beech & 7.74900 & $3.50 \mathrm{E}-09$ & 2.01746 \\
\hline
\end{tabular}

(If $F>F$ crit, then variances between treatment groups are larger than within groups, small P-values indicate high significance of results)
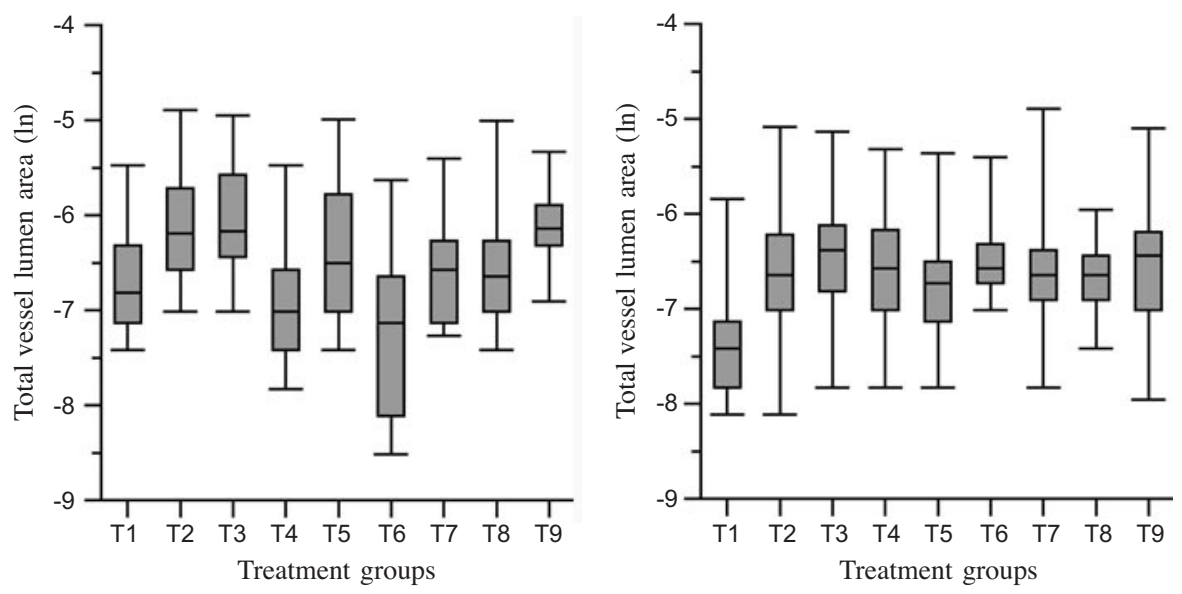

Figure 5. Total vessel lumen area (log-transformed) per treatment (T1-9) for alder (left) and beech (right); box-plots show five important numbers: the box in the centre spans the quartiles; the horizontal line in the centre marks the median; the vertical lines extending out from the box are capped by horizontal lines often called whiskers indicating minima and maxima (Cleveland 1994). 
sion in both species in groups $\mathrm{T} 1$ to $\mathrm{T} 3$ from smaller to relatively larger total vessel lumen areas. In both species, total vessel lumen area decreased less when the apex was cut (T5), possibly because the apex is required for response to gravitational forces (Strasburger et al. 2002). This seems comparable to the altered percentage of fibre cell wall material in this group (Fig. 4). It may be that, to some extent, the dimensions of vessel lumens and fibre cell walls might eventually be used to classify tension wood formed in response to a gradient of mechanical stresses.

However, the box-plots also show that total vessel lumen areas do not necessarily correlate with percentages of cell walls in fibres. For example, in alder, treatment T6 resulted in significantly smaller total vessel lumen area relative to T7, whereas in beech the total vessel lumen areas of T6 and T7 are not different. This might suggest that both fibre cell and vessel formation in alder are hindered by the effects of tissue removal from above the impact zone, but that this might not be true in beech. Furthermore, vessel areas for beech in treatment T4 (apex vertical) are slightly but insignificanly larger in T5 (apex cut), whereas in alder the total vessel area of T5 is significantly greater than that of $\mathrm{T} 4$.

Overall, the results presented here suggest that the additional application of wood anatomical techniques can help identify different degrees of tension wood formation. This study shows for the first time that the area of vessel lumens and the relative amount of wall material comprising the fibres of alder and beech are factors that potentially can complement dendrogeomorphologic studies based otherwise only on ring width measurements or simple ring counts. The preliminary results demonstrate that differences in the formation of tension wood might be used to infer the nature of various geomorphic events and processes in greater detail. However, attention needs to be paid to trees that have not only been bent but also damaged, in which case the development of the tension wood is likely to be altered even further. Additional analyses are needed to confirm and refine these preliminary results and to specifically test the hypothesis that wood anatomical techniques can be used to reconstruct the kind and size of geomorphic phenomena in greater detail.

\section{ACKNOWLEDGEMENTS}

The authors wish to thank the Swiss National Science Foundation (SNF) for funding the project. We would like to express our gratitude to the local foresters Urs Andenmatten, Leo Jörger, Beat Zurbuchen and Jacques Galley for their help with the site selection. We are very grateful to Britta Eilmann, Jacqueline Bolli and Clarissa Zurwerra (all WSL), Stefan Winter (Geography, University of Fribourg) and Raphael Holland (Geography, University of Bonn) for their help with the sample collection and preparations.

\section{REFERENCES}

Alestalo, J. 1971. Dendrochronological interpretation of geomorphic processes. Fennia 105, Helsinki.

Arganbright, D.G. \& D.W. Bensend. 1968. Relationship of gelatinous fiber development to tree lean in soft maple. Wood Science 1: 37-40.

Bland, D.E. \& G. Scurfield. 1964. The chemistry of reaction wood. Part IV. The distribution and nature of the lignin in seedlings of hardwoods. Holzforschung 18: 161-166. 
Burns, G.P. 1920. Eccentric growth and the formation of redwood in the main stem of conifers. Vt. Agr. Sta. Bull. 219: 1-16.

Chow, K.Y. 1946. A comparative study of the structure and chemical composition of tension wood and normal wood in beech (Fagus sylvatica L.). Forestry 20: 62-77.

Clague, J. J. \& J.G. Souther. 1982. The dusty creek landslide on Mount Cayley, British Columbia. Can. J. Earth Sci. 19: 524-539.

Clair, B. \& B. Thibaut. 2001. Shrinkage of the gelatinous layer of poplar and beech tension wood. IAWA J. 22: 121-131.

Cleveland, W.S. 1994. The elements of graphing data. Hobart Press, Summit, NJ.

Cook, R.D. \& S. Weisberg. 1999. Applied regression including computing and graphics. John Wiley \& Sons, Hoboken, NJ.

Côté, W.A. \& A.C. Day Jr. 1965. Anatomy and ultrastructure of reaction wood. In: W.A. Côté (ed.), Cellular ultrastructure of woody plants: 391-418. Syracuse University Press, Syracuse, NY.

Forster, T., F.H. Schweingruber \& B. Denneler. 2000. Increment puncher: A tool for extracting small cores of wood and bark from living trees. IAWA J. 21: 169-180.

Gärtner, H., M. Stoffel, I. Lièvre \& M. Monbaron. 2003. Tree ring analyses and detailed geomorphological mapping on a forested debris flow cone in Switzerland. In: D. Rickenmann \& Ch. Chen (eds.), Debris flow hazards mitigation: mechanics, prediction, and assessment, Vol. 1: 207-217.

Höster, H.R. \& W. Liese. 1966. Über das Vorkommen von Reaktionsgewebe in Wurzeln und Ästen der Dikotyledonen. Holzforschung 20: 80-90.

Hughes, F.E. 1965. Tension wood. A review of literature. Part II. Forestry Abstracts 26: 179186.

Kennedy, R.W. \& J.L. Farrar. 1965. Tracheid development in tilted seedlings. In: W.A. Côté (ed.), Cellular ultrastructure of woody plants: 419-453. Syracuse University Press, Syracuse, NY.

Lowell, E.C. \& R.L. Krahmer. 1993. Effects of lean in red alder trees on wood shrinkage and density. Wood Fiber Sci. 25: 2-7.

Mattheck, C., K. Weber \& K. Gotz. 2000. Wie die Rotbuche radiale Zugbelastungen bewältigt. Allgem. Forst- u. Jagdzeitung 171: 10-14.

Nicholson, J.E. 1973. Growth stress differences in eucalypts. Forest Science 19: 169-174.

Nicholson, J.E., W.E. Hillis \& N. Ditchburne. 1975. Some tree growth-wood property relationships of eucalypts. Can. J. For. Res. 5: 424-432.

Robards, A.W. 1966. The application of the modified sine rule to tension wood production and eccentric growth in the stem of crack willow (Salix fragilis L.). Ann. Bot. 30: 513-523.

Sachsse, H. 1961a. Untersuchungen über Eigenschaften und Funktionsweise des Zugholzes der Laubbäume. J.-D. Sauerländer, Frankfurt a. M.

Sachsse, H. 1961b. Anteil und Verteilung von Richtgewebe im Holz der Rotbuche. Holz RohWerkstoff 19: 253-259.

Schweingruber, F.H. 1996. Tree rings and environment. Dendroecology. Swiss Federal Institute for Forests, Snow and Landscape Research, Birmensdorf and Paul Haupt, Bern, Stuttgart, Wien.

Schweingruber, F.H. 2001. Dendroökologische Holzanatomie. Anatomische Grundlagen der Dendrochronologie. Eidgenössische Forschungsanstalt WSL, Birmensdorf and Paul Haupt, Bern, Stuttgart, Wien.

Scurfield, G. 1973. Reaction wood: its structure and function. Science 179: 647-655.

Strasburger, E., P. Sitte, E.W. Weiler, J.W. Kadereit, A. Bresinsky \& C. Körner. 2002. Lehrbuch der Botanik für Hochschulen. Spektrum Akademischer Verlag, Heidelberg, Berlin. 
Tesari, J. \& C. Mattheck. 1999. Die Anpassung der Druckfestigkeit von Laubholzästen an die Belastung durch Eigengewicht. Allgem. Forst- u. Jagdzeitung 170: 128-132.

Trénard, Y. \& P. Guéneau. 1975. Relation entre contraintes de crossance longitudinals et bois de tension dans le hêtre (Fagus sylvatica L.). Holzforschung 29: 217-223.

Wardrop, A.B. 1956. The nature of reaction wood. Austr. J. Bot. 4: 152-166.

Wardrop, A.B. 1964. Reaction anatomy of arborescent angiosperms. In: M.H. Zimmermann (ed.), Formation of wood in forest trees: 405-456. Academic Press, New York.

Willits, S.T., T.A. Snellgrove \& M.E. Plank. 1990. Lean in red alder: its effect on product volume and quality. Forest Prod. J. 40: 31-34.

Wilson, B.F. \& B.L. Gartner. 1996. Lean in red alder (Alnus rubra): growth stress, tension wood, and righting response. Can. J. For. Res. 26: 1951-1956.

Yumoto, M., S. Ishida \& K. Fukazawa. 1983. Studies on the formation and structure of the compression wood cells induced by artificial inclination in young trees of Picea glauca. IV. Gradation of the severity of compression wood tracheids. Res. Bull. Coll. Exp. For. Hokkaido Univ. 40: 409-454. 